\title{
Colloquy
}

\section{HOME OTHERWISE: Living Archives and Half-Life Politics in Post-Fallout Coastal Fukushima}

\author{
RYO MORIMOTO \\ Princeton University \\ (iD https:/ / orcid.org/0000-0001-7986-8109
}

During my fieldwork in the coastal region of Fukushima prefecture, I often accompanied Naoko, a woman in her eighties, into the evacuation zone of Minamisōma, where she grew up, to tend to her abandoned, contaminated residence. Naoko was one of the twenty thousand Minamisōma residents displaced in the wake of the 2011 nuclear disaster. Each visit, she would enter her former bedroom, open the drawers of the dresser, and quietly contemplate the items within. She would remove a few things from the drawer and lay them on the floor, as if to indicate her willingness to transfer them somewhere else. Then, she would clean up the area around the family's Buddhist altar in the adjacent room. As she offered incense, the smoke rose to the wall where photographs of her deceased family members hung. Their cremated remains rest in the family grave on their property, a few hundred feet away from the house. The altar, memorial portraits, and the grave together articulate Naoko and her family's multiple relationalities and temporalities, archived in the place they called home. Right before our departure, Naoko would once again return her belongings to the drawer. This contaminated home, not her temporary residence nine miles north of the evacuation zone, is where she wishes to rest in peace when the time comes. 
Unlike in other post-fallout regions like Chernobyl, the Japanese government has been gradually reopening areas it originally deemed unhabitable following the failure of the Tokyo Electric Fukushima Daiichi Nuclear Power Plant. In August 2011, the government's decontamination policy sketched a hopeful image for Minamisōma's displaced residents who wished to reclaim their land and livelihoods. Naoko was one of many in the Odaka district who clung to the government's promise to reopen the evacuation zone. ${ }^{1}$ Despite the higher risk of radiological exposure, for the evacuees, the idea of home - as both an enduring, contaminated physical structure, and a remote and nostalgic place-has become inseparable from their idea of dying well (ii shinikata).

How can people die well in post-fallout coastal Fukushima? Alternatively, how do people maintain their home and the idea of home, despite and because of the fallout? In Greek and Japanese conceptualizations, the home (oikos and ie, respectively) constitutes a historical collection of relations and affects that extends across the living, the dead, and the not-yet-born. Home is not only a material structure in which one lives, sheltered from the outside world and de/contaminated. It is also a semiotic terrain where concepts such as lineage, genealogy, kinship, memory, and belonging are performed and (re)produced through processes of house-ing: individual, social, economic, material, religious, cultural, and repair work (as also discussed by Federico Neiburg [2021, this issue] and by Thiago da Costa Oliveira and Carlos Fausto [2021, this issue]). As a living, processually unfolding archive of multiple relationalities, the home remains a vital resource through which evacuees make sense of the protracted afterlife of the triple disaster - earthquake, tsunami, and nuclear fallout (Morimoto 2012).

In his analysis on the expansive parameters of U.S. national security in "the age of fallout," Joseph Masco (2015) argues that the planetary consequences transcend ecological, geographical, political, and sociocultural boundaries. Yet the experiences of the Fukushima residents I met challenge this framing of the fallout as a universalizing equalizer. Instead, in the aftermath of the accident and throughout the recovery process, radiological contamination has unequally threatened certain bodies and materials. In the event of planetary injuries, settling our attention at the scale of the home can reveal that contamination is not a fixed state. It is, first, a process negotiated through the act of making, unmaking, and remaking home.

In late 2013, more than two years after the initial evacuation, the government began decontaminating the region surrounding Naoko's home. Eventually, governmental officials proposed to demolish Naoko's home at no cost, and her family consented, as the earthquake that catalyzed the nuclear meltdown had par- 
tially damaged their house. Thus, a year later, I returned with Naoko to visit her residence. This time, her task was to identify which items would be preserved from the demolition and which would be disposed of as contaminated "waste." She planned to transfer the valuables to a warehouse next to the family's house, where they kept farming tools and machinery.

In this selection process, Naoko became more vocal about the items I had seen her unpack and repack many times before. Contemplating a kimono she had not worn in ages, she asked me: "What do I do with this? Even if I keep this kimono, no one is gonna wear it, including myself." She touched the faded gray fabric. "To tell you the truth," Naoko confessed, "I might have worn this only a few times. It was from sixty years ago when I married in this house." When I asked her if she would throw away her kimono, she replied, "The demolition date has not been set yet. I could keep it for the time being. I mean, isn't it a nice kimono?" She stroked the kimono before folding it with care and returning it to the dresser, closing the drawer with deliberate force. It sounded heavy, as if the dresser carried all the sedimented memories of her life in the house.

On the way back to her temporary residence where her son and his family waited, Naoko spoke about the difficulty of letting things go: "My family said to throw away any unnecessary things in my life. But the more I thought about each item, the more I felt that my life was being taken away by the disaster and reconstruction."

Preserving her things was Naoko's way of resisting the inertia of the government's reconstruction-through-decontamination initiative. Even though she desired to return to her home - and, by extension, for it to be decontaminated - Naoko was not ready for her personal belongings to be "cleaned up" and transformed into waste, along with the physical existence of her home and the land she cultivated.

Although decontamination purports to clean up contaminants, it also entails the large-scale destruction of people's familiar environments. The government's initiative engages what I call a half-life politics: policies and practices that foreground the presence and absence of radiation in the environment and their potential harm to humans above all other things, such as the residents' quality of life, cultural continuity, memories, the sustainability of their livelihoods, and biodiversity. Moreover, by pursuing the removal of contaminants above all else, government policies paradoxically foreclose evacuees from accessing state-sanctioned resources by proving their damaged biology, or what Adriana Petryna (2013) calls "biological citizenship." In this context, my oikography instead centers on the rela- 
tional assemblage of the home as the grounds for making meaning and value in the protracted shadow of nuclear fallout.

In June 2019, over eight years after her initial evacuation, Naoko finally reunited with her inalienable belongings. In place of her old one-story farmhouse stood a modern two-story house, with a shinier and more elaborate altar. Although they certainly desired a home with less measurable contamination, evacuees like Naoko found their decontaminated and renovated homes rather unhomely. Contaminants - radioactive isotopes — sit on the surface of memories and meanings built up and through the home. Decontamination, by way of demolition, necessitated the removal of the entire structure. Purity, in this instance, endangers historicity.

During the building of the new house, Naoko had transferred the altar to the warehouse. As part of the ritual that marks moving into a new home, she had acquired a new altar. This, however, required Naoko to securely transfer the ancestral spirits from the old altar to the new one. "It was challenging to move the spirits," she told me. While cleaning the former altar in the warehouse, "a Buddhist monk came and chanted to transfer the spirits from one altar to the other. It is funny how the deceased get better treatment than the living ones. No one prayed for me!" Naoko's sarcasm provided a not-so-veiled critique of the government's decontamination policy, which lacked any consideration for disaster-related damages beyond biomedically significant radiation exposure. For officials, her return to the now supposedly decontaminated region signaled the success of their remediation efforts - Naoko was yet another statistic proving the safety of the area.

As the altar movers arrived to dispose of the now spiritless old altar, Naoko proudly told them how thoroughly she had cleaned it to signal her care and respect for the house her ancestral spirits had previously occupied. Yet one of the workers voiced his concern that the altar actually looked too clean: it did not look like a deserted altar in an evacuated home. After chatting among themselves, a younger staff member asked Naoko if it was alright for them to make the altar "look dirtier" - it was their routine way for documenting that an altar belonged to a displaced family. The procedure would allow Naoko's family to receive a higher compensation for the altar's disposal, he said. Without securing Naoko's consent, the worker grabbed the incense ash holder and spread ashes over the old altar. Photographing the spoiled altar from multiple angles, he exclaimed, "It looks much better!" He then assured Naoko that the photos of the adequately "ruined" altar would garner her family one hundred thousand yen (around ten thousand dollars), which they deserved for the lost time. Watching the departing truck with the old 
altar, Naoko lamented that "the ruined altar is worth something, but what about my last eight years of waiting and more wrinkles on my face?"

Now there remains one less item in the warehouse full of misplaced things from the past with no economic value, including Naoko's kimono. She was unable to find a place for it in her modernized residence. In the absence of the old altar, the other items she had kept looked out of place. Naoko told her family to throw all her belongings away once she dies. For the time being, she insists that "so long as I live, I need them as proof that I lived in Odaka." The tangible proof is what Naoko desired to live as fully as she could despite the fallout and its enduring aftermath.

In the context of a crisis and its protracted aftermath, ie becomes an illuminating ethnographic subject and scale of analysis. Echoing Neiburg's (2021) poignant observation, people use objects in their homes to order the world around them. In turn, these objects - their presence, absence, historicity, and biography_come to order people (Hastrup 2011; Manning 2012). Through this mutual house-ing, planetary injuries from the fallout crystalize in the mundane and once familiar homes (former, temporary, and current) of evacuees like Naoko. Sometimes, it takes an impractical piece of memorabilia to sustain one's sense of belonging. Other times, it takes intentional ruination to accept the irreversible flow of time. As an archive of multiple material-semiotic relationalities of people, things, and the environment, the home offers insight into the process through which people attempt to make themselves whole again on an already injured planet.

\begin{abstract}
While the 2011 nuclear disaster in Japan forced residents out of their coastal Fukushima homes, transforming familiar ecologies into sites of estrangement, Naoko and neighbors remain invested in the material objects and spiritual relations of their houses, within and despite the logics of contamination. These desires to repair domestic livelihoods to nurture a sense of home (ie) and the idea of dying well (ii shinikata) challenge critical theories of nuclear fallout, which frame contamination's impacts in terms of biopolitical logics and planetary scales. Thus, although contamination regiments the lives of residents through what I call a half-life politics, their practices of house-ing defy these strictures, as planetary contamination becomes experiential, ethnographic, and interscalar, and as people attempt to remake lives in an already injured and irradiated world. [nuclear fallout; contaminated home; biopolitics and half-life politics; semiotics; archives and belonging; Japan]
\end{abstract}




\section{要旨}

2011 年東日本大震災に起因する東京電力福島第一発電所事故は近隣の森や 生態系を污染し、多くの福島県浜通り地区の住民達を長期避難に追いやった。し かしながら住民の多くは污染されなくなく避難した『家』との縁を切るのではな く、個々の考える『いい死に方』を求め污染された家との物質的、精神的つながり 求め続けた。このような避難民の原子力事故後の行動は、人間と放射性物質の関 係性を生物的ダメージに特化して語るフォールアウト関連の学術的思考や、事故 後の政策に見られる污染中心の『半減期的政治』とは異なる考え方の必要性を示 している。この論文は文化人類学的アプローチを使い、人はどのようにして『家』 を保持しようとする行動の中で自分以外のモノとのつながりを認知し、放射能污 染の様々な規模 一その地域性や普遍性- を理解し、それと共存して行こうとす るのかという問いへの回答を探る。[原子力災害; 污染された家; 生政治と半減期 政治;記号学;アーカイブと縁]

\section{RESUMO}

Enquanto o desastre nuclear de 2011 no Japão forçou os residentes de Fukushima a abandonar suas casas, transformando ecologias familiares em locais de estranhamento, Naoko e seus vizinhos continuam a investir em objetos e em relações espirituais com as suas casas agora emolduradas pela lógica da contaminação. O desejo de recuperar o sentido de lar (ie) e a ideia de morrer bem (ii shinikata) desafia as teorias críticas da contaminação radioativa que maiormente enfatizam o seu impacto em termos biopolíticos e em escala planetária. Assim, embora a contaminação regule o dia a dia dos moradores através do que eu chamo de half-life politics, suas práticas de house-ing desafiam essas restrições. A etnografia revela a contaminação planetária como sendo experiencial e interescalar, e mostra as pessoas refazendo as suas vidas em um mundo já irradiado e ferido. [acidente nuclear; casa contaminada; biopolítica e half-life politics; arquivos e pertencimento; Japão].

\section{RESUMEN}

Mientras el desastre nuclear de 2011 en Japón obligó a los residentes de Fukushima a abandonar sus hogares, transformando ecologías familiares en lugares de extrañamiento, Naoko y sus vecinos siguen invirtiendo en objetos y en relaciones espirituales con sus casas ahora envueltas en la lógica de la contaminación. Los deseos de recuperar el sentido de hogar (ie) y la idea de morir bien (ii shinikata) desafían las teorías críticas sobre la contaminación radioactiva que en su mayoría enfatizan los impactos biopolíticos y la escala planetaria. Así, aunque la contaminación regula el cotidiano a través de lo que llamo half-life politics, las prácticas de house-ing desafían estas restricciones. La etnografía revela a la contaminación planetaria como experiencial e interescalar y muestra a las personas rehaciendo sus vidas en un mundo ya herido e irradiado. [accidente nuclear; casa contaminada; biopolítica y halflife politics; archivos y pertenencia; Japón] 


\section{NOTES}

Acknowledgments My deep gratitude goes to numerous residents of Minamisōma for allowing an outsider like myself to be part of their postfallout lives. I want to thank Federico Neiburg and João Biehl for including my piece in their exciting series. Also, I thank Hollianna Bryan and Beth Semel for their editorial assistance. All errors are my own.

1. About 13,000 residents evacuated Odaka in March 2011. It was reopened in July 2016. As of September 2021, about 4,340 residents are living in Odaka.

\section{REFERENCES}

Costa Oliveira, Thiago da, and Carlos Fausto

2021 "Amazonian House-ing: A Visual Anthropology Essay." Cultural Anthropology 36, no. 4: 580-88. https://doi.org/10.14506/ca36.4.06.

Hastrup, Frida

2011 Weathering the World: Recovery in the Wake of the Tsunami in a Tamil Fishing Village. New York: Berghahn Books.

Manning Paul

2012 Semiotics of Drink and Drinking. London: Continuum International.

Masco, Joseph

2015 "The Age of Fallout." History of the Present: A Journal of Critical History 5, no. 2: 137-68. https://doi.org/10.5406/historypresent.5.2.0137.

Morimoto, Ryo

2012 "Shaking Grounds, Unearthing Palimpsests: Semiotic Anthropology of Disaster." Semiotica 192: 263-74. https://doi.org/10.1515/sem-2012-0088.

Neiburg, Federico

2021 "Multiscale Home: Shifting Landscapes and Living-in-Movement in Haiti." Cultural Anthropology 36, no. 4: 548-55. https://doi.org/10.14506/ca36.4.02.

Petryna, Adriana

2013 Life Exposed: Biological Citizens after Chernobyl. Princeton, N.J.: Princeton University Press. 